This is an electronic reprint of the original article. This reprint may differ from the original in pagination and typographic detail.

Author(s): Leppäniemi, Matti; Karjaluoto, Heikki; Saarijärvi, Hannu

Title: $\quad$ Customer perceived value, satisfaction, and loyalty : the role of willingness to share information

Year: $\quad 2017$

Version:

Please cite the original version:

Leppäniemi, M., Karjaluoto, H., \& Saarijärvi, H. (2017). Customer perceived value, satisfaction, and loyalty : the role of willingness to share information. International Review of Retail, Distribution and Consumer Research, 27(2), 164-188.

https://doi.org/10.1080/09593969.2016.1251482

All material supplied via JYX is protected by copyright and other intellectual property rights, and duplication or sale of all or part of any of the repository collections is not permitted, except that material may be duplicated by you for your research use or educational purposes in electronic or print form. You must obtain permission for any other use. Electronic or print copies may not be offered, whether for sale or otherwise to anyone who is not an authorised user. 


\title{
Customer perceived value, satisfaction, and loyalty: The role of willingness to share information
}

\begin{abstract}
This study proposes and tests an integrative model to examine the relationships among customers' willingness to share information, satisfaction, perceived value, and loyalty in a retailing context. Customer information is a cornerstone of contemporary marketing activities and increasingly important for any business and for successful customer relationship management (CRM). This study extends research on customers' willingness to share information from trust and privacy concerns toward key outcome measures such as perceived value, customer satisfaction, and loyalty, and is thus among the first ones to model customers' willingness to share information with companies in robust theoretical retailing frameworks. The proposed relationships were tested using data from two retailing contexts - groceries $(\mathrm{N}$ $=429)$ and do-it-yourself (DIY) $(\mathrm{N}=895)$. The data were analyzed using partial least squares structural equation modeling. Findings from the two samples suggest that both perceived value and satisfaction are significant determinants of customers' willingness to share information with a company. Although some differences emerge in the two studies, structural modeling largely supports the hypothesized framework and positions customers' willingness to share information as an important antecedent of their loyalty intentions and behavior. This study provides practitioners with preliminary insight into the relationship between willingness to share information and perceived value, customer satisfaction, and customer loyalty. This study advances retailing research, as it is one of the few empirical studies investigating the role of customers' willingness to share information in driving loyalty and its relationship with perceived value and satisfaction in a retailing context.
\end{abstract}

Keywords Willingness to share information, perceived value, satisfaction, share of wallet, customer loyalty 


\section{Introduction}

In the past decade, the retailing environment has changed dramatically due to the advent of the online channel and ongoing digitalization (Verhoef, Kannan, and Innan 2015). Customers have access to a vast amount of information and have a wide variety of alternative services, products and suppliers to choose from. As a result, customers are more demanding, and it is difficult for companies to gain their loyalty (Kumar and Reinartz 2012). To succeed in a competitive and dynamic marketplace, companies need to better understand their customers and to respond to customers' wants and needs more quickly (Grosso and Castaldo, 2015). Consequently, companies are increasingly gathering and analyzing information about their customers' preferences and buying behavior. Companies with information about their consumers' preferences and desires are better able to enhance customer service (Richards and Jones 2008); explore opportunities for product and service development (Jayachandran et al. 2005); and potentially increase their most valuable customers' commitment and share-ofwallet, retain customers and increase their profitability (Miceli, Raimondo, and Farace 2013; Pfeifer and Ovchinnikov 2011).

At the same time, customers are becoming increasingly aware that companies are constantly collecting, storing and processing vast amounts of highly detailed information about them. Consequently, companies are faced with the pressure of converting customer information into competitive advantage while balancing customers' willingness to share their information with the companies. As discussed by Schoenbachler and Gordon (2002), the fact that companies are increasingly collecting their customers' personal information creates privacy concerns, and consumers may perceive a risk of marketers or third parties abusing this information. Hence, consumers' willingness to share data with companies is a critically important pre-requisite for understanding the evolution of changing customer needs, developing products and services on the basis of that understanding, accumulating a loyal customer base, and building successful long-term customer relationships.

Despite the fact that data-driven initiatives offer compelling relationship-building opportunities for customer-centric companies, customers' willingness to share information with relationship-seeking marketers remains relatively understudied (Phelps, Nowak, and Ferrell 2000; White 2004; White, Novak, and Hoffman 2014). Most prior studies have focused on disclosure avoidance, arguing that consumers' concerns regarding trust (Metzger 2004, 2006; Olivero and Lunt 2004) and the privacy of their personal information are the main drivers of consumers' decision not to disclose information to marketers (John, Acquisti, 
and Loewenstein 2011; Mothersbaugh et al. 2012). Previous studies have identified risk perception, credibility, past experience, company reputation, and perceived dependability as important antecedents of trust, which in turn is linked with consumers' willingness to provide information (Schoenbachler and Gordon 2002). Moreover, companies' privacy policy statements and other privacy assurance measures have been identified as important features that increase consumers' trust and willingness to disclose information (Milne and Culnan, 2002, 2004). In fact, consumers' privacy concerns moderate the effect between these privacy assurance mechanisms and trust. Consequently, despite the fact that individuals vary in their perceptions of privacy concerns (Bansal, Zahedi, and Gefen 2015), the way companies succeed in privacy assurance largely determines how they are able to reduce privacy concerns and build trust (Wu, Huang, Yen, and Popova 2012). The topic of privacy concerns has been studied extensively, and it has been identified as a focal construct within the contemporary business landscape, and as Greenaway, Chan, and Crossler (2015) discuss, it contains various ethical, legal, and information management issues. In addition, a few studies have considered relational commitment (Lacey and Morgan 2008), relationship quality (White 2004), and compensation or incentives for providing information (Premazzi et al. 2010; White, Novak, and Hoffman 2014) as relevant antecedents of customers' willingness to share information with marketers. Nevertheless, little explicit attention has been given to other factors that may affect customers' willingness to share information with a company.

The majority of prior research on customers' willingness to share personal information has been conducted in an online context (e.g. Metzger 2004, 2006; Wang, Beautty, and Foxx 2004). One of the key reasons for this is that collecting and using customers' personal information is vital for the survival of online stores (Metzger 2004). However, early research indicates that many customers have been reluctant to provide information in an online environment for various reasons, most notably privacy and security concerns, including lack of trust in the online experience (Metzger 2004, 2006). In addition, with the exception of the studies conducted with customers of a casual dining restaurant chain (Lacey and Morgan 2008) and catalog or direct marketing companies (Phelps, Nowak, and Ferrell 2000; Schoenbachler and Gordon 2002), little theoretical and empirical research has been performed to understand the influence of factors beyond trust and privacy that may affect customers' willingness to share information (WSI) with retailers. Conclusively, it can be argued that current understanding of how WSI influences their loyalty intentions and behavior is incomplete. 
Drawing from equity theory (Adams 1965), exchange theory (Bagozzi 1975), and research on mental accounting (Thaler 1985), this research aims to fill the previously mentioned gaps in the literature by proposing and testing an integrative model that examines the relationships among WSI, perceived value, satisfaction and loyalty in a retailing context. Thus, the study complements existing research on traditional antecedents of customers' WSI, such as perceived trust and customer privacy, toward key managerial outcomes. Specifically, this paper has two major objectives: to examine the antecedent role of perceived value and satisfaction in customers' WSI and to explore how customers' proportion of overall spending allocated to a particular firm, i.e., share-of-wallet (Bowman and Narayandas 2004), and subsequent loyalty intentions are influenced by their WSI.

The study is noteworthy for several reasons. First, unlike prior studies, the current study models customer perceived value and satisfaction as antecedents of WSI with a company. This focus is theoretically and managerially appealing because these antecedents are rooted in strong theoretical frameworks and because the results should advance our understanding of factors that are likely to be among the key drivers of customers' WSI with a relationship-seeking company. Moreover, customer data is becoming an increasingly important resource for value creation - both for firms and customers, and customers' WSI is a critical prerequisite for this value creation. Therefore, it is vital to build new theoretical linkages between customers' WSI and key outcome measures, such as customer perceived value and customer satisfaction.

Second, WSI is not studied in isolation. Rather, we test a model that proposes interrelationships among customer perceived value, satisfaction and loyalty (both intentions and behavior) and includes customer WSI as an important mediating variable. This approach allows us to gain (1) insights into the role of customers' personal information sharing in relational exchanges and (2) an understanding of the effects of customers' WSI on loyalty intentions (repurchase and recommend) and behavior (share-of-wallet). Third, a vast majority of prior research on information sharing has been conducted in an online context. We contribute to the existing literature by testing our model in an offline context. Specifically, we perform our research in two different retail settings, groceries and do-it-yourself (DIY).

The remainder of the article is organized as follows. First, we present the proposed conceptual model and develop our hypotheses. Subsequently, we describe the research method used to test the hypotheses and the empirical results. We then discuss our findings and theoretical and managerial implications. We conclude with a discussion of the limitations of our study and possible topics for future research. 


\section{Conceptual framework and hypothesis development}

As an overview of the model, we propose that customers' share-of-wallet and subsequent loyalty intentions are influenced by their WSI with a company. In addition, perceived value and satisfaction are hypothesized to facilitate customers' WSI (see Fig. 1).

"Insert Figure 1 about here"

The impact of perceived value on loyalty and willingness to share information

Customer value is "the fundamental basis for all marketing activity" (Holbrook 1994, 22). Based on equity theory (Adams 1963, 1965), Zeithaml $(1988,8)$ defines customer value as "the consumer's overall assessment of the utility of a product based on the perceptions of what is received and what is given." Numerous academic and practitioner studies support this cost-benefit perspective of customer value (e.g., Brodie, Whittome, and Brush 2009; Gale 1994; Varki and Colgate 2001).

Loyalty is often viewed as consisting of an attitudinal and a behavioral component (Kumar, Dalla Pozza, and Ganesh 2013). In terms of attitudinal loyalty, prior research has often treated repurchase intention and recommend intention (WOM) as components of loyalty rather than as two distinct constructs (see e.g., Sirdeshmukh, Singh, and Sabol 2002; Zeithaml, Berry, and Parasuraman 1996). However, recent meta-analyses of studies on loyalty have questioned this "cocktail approach" (Söderlund 2006, 78). Based on their analyses, both de Matos and Rossi (2008) and Watson et al. (2015) support the argument that repurchase intention and WOM should be considered as separate constructs and that a unidimensional approach should be avoided. In line with de Matos and Rossi (2008) and Watson et al. (2015), the present study treats repurchase intention and recommend intention as distinct constructs.

According to Seiders et al. (2005), repurchase intention is defined as the likelihood that a customer will engage in future repurchase behavior. In the line with Zeithaml, Berry, and Parasuraman (1996), recommend intention is defined as the likelihood that a customer will recommend and say positive things about company $\mathrm{X}$ to others. Several studies have provided empirical evidence of the positive relationship between customer perceptions of value and customer loyalty (Brodie, Whittome, and Brush 2009; Grosso and Castaldo 2015; Sirdeshmukh, Singh, and Sabol 2002; Yang and Peterson 2004). Specifically, prior studies 
have shown that customer perceived value is a major antecedent of repurchase intention (Baker et al. 2002; Grewal, Monroe, and Krishnan 1998; Zeithaml 1988). In addition, a number of studies have provided empirical evidence of a linkage between perceived value and recommend intention (Gruen, Osmonbekov, and Czaplewski 2006; Hartline and Jones 1996; McKee, Simmers, and Licata 2006). Therefore, we propose the following hypotheses:

H1. Perceived value is positively related to REPINT.

H2. Perceive value is positively related to RECINT.

Companies are increasingly interested in observing customer loyalty behavior rather than loyalty intentions (Kumar, Dalla Pozza, and Ganesh 2013) because the former can be directly linked to revenues and profitability (Chandon, Morwitz, and Reinartz 2005; Keiningham et al. 2007). Companies have used several different measures of behavioral loyalty, including retention, lifetime duration, usage, and cross buying (e.g., Bolton and Lemon 1999; Mittal and Kamakura 2001; Seiders et al. 2005). Recently, both scholars and practitioners have begun to focus their attention on share-of-wallet as a measure of customer loyalty behavior (Cooil et al. 2007; Kumar, Dalla Pozza, and Ganesh 2013; Grosso and Castaldo 2015). According to Bowman and Narayandas (2004), share of wallet is defined as the proportion of overall spending (in a category) allocated to a particular firm.

The expectation of a link between perceived value and SOW has underpinnings in equity theory. According to equity theory, people should receive benefits or outcomes in proportion to their own relative efforts or the inputs that they contribute (Adams 1965; Carrell and Dittrich 1978). In conducting comparisons of input-outcome ratios, customers assess their relationship with the company on the basis of the appropriateness of their own ratio of efforts to benefits compared with the outcome-input ratio of the company (Oliver and DeSarbo 1988; Steinhoff and Palmatier 2016). Perceptions of inequity (i.e., input $>$ outcome) often result in feelings of unfairness, which evoke negative customer reactions (Samaha, Palmatier, and Dant 2011). Therefore, we suggest that perceived inequality may manifest as a company's receipt of a low percentage of a customer's total expenditure. By contrast, if customers feel as though they have been treated equitably, they tend to spend more money at a company that offers better value for their money. In a retailing context, prior studies have shown a positive relationship between perceived value and SOW (Babakus and Yavas 2008). Similarly, in business markets, customer perceived value is positively related to SOW (Eggert and Ulaga 2010; Hughes, Le Bon, and Rapp 2013). Thus, we formulate the following hypothesis: 
H3. Perceived value is positively related to SOW.

Customers typically engage in information exchange with retailers to gain benefits that may be utilitarian, hedonic, or symbolic in nature (see Rintamäki et al. 2006). In a retailing context, exchange costs and benefits seldom occur simultaneously; therefore, a certain amount of risk and uncertainty are involved in customers' decisions to share information with a company. For example, if a customer decides to enroll in a loyalty program, he or she must provide resources (such as personal information and access to purchase history) to receive benefits in the future (such as monetary savings or special service). Therefore, a retailer's offer (i.e., benefits) related to information gathering (such as joining a loyalty program) can be considered to be contingent (Thaler 1985); that is, the offer is conditional in the sense that consumers are required to provide resources for the exchange to occur (White, Novak, and Hoffman 2014).

Because benefits and costs are mainly known (such as reward structure, participation requirements, and payment function in the loyalty program), we suggest that customers tend to maintain mental accounts of the expected benefits and expected costs of sharing personal information, and they do so only to the extent that they perceive net benefits of sharing information (Derlega et al. 2008; White, Novak, and Hoffman 2014). Mental accounting research (Thaler and Johnson 1990) suggests that consumers have to mentally integrate the value of both given and received resources to formulate an overall outcome evaluation before they respond to a marketer's contingent offer. Because consumers must actively assess exchange costs to judge the net disclosure benefits, we expect that consumers' prior perceptions of value provided by the company impact the assessment. Thus, consumers' value perceptions are likely to enhance net exchange benefits and improve the likelihood that consumers will engage in information exchange. Prior studies on consumers' disclosure behavior have corroborated this view by showing that perceived benefits and costs have direct effects on customers' willingness to disclose personal information to relationship-seeking marketers (Dinev and Hart 2006; Xu et al. 2009). Thus, we formulate the following hypothesis:

H4. Perceived value is positively related to WSI.

The impact of customer satisfaction on loyalty and WSI 
Much of past studies have considered satisfaction as an affective response to an expectancy disconfirmation (see e.g., Oliver 1993). For instance, Tse and Wilton $(1988,204)$ define satisfaction as 'the consumer's response to the evaluation of discrepancy between prior expectations and the actual performance of the product as perceived after its consumption". Customers make repurchase decisions based on their future expectations about the value of a product, service or brand, and their expectations are derived from prior experiences with the product, service or brand (Bolton, Kannan, and Bramlett 2000). Accordingly, we conceptualize customer satisfaction as a cumulative, global evaluation based on experience with a firm over time (Seiders et al. 2005).

Much of the early research has reported a positive relationship between customer satisfaction and repurchase intention (Garbarino and Johnson 1999; Grosso and Castaldo 2015; Shankar, Smith, and Rangaswamy 2003). More recently, the link has also been confirmed in the retailing context (e.g., Friedman, Brown, and Taran 2011). Customer satisfaction is also considered an antecedent of recommend intention. Indeed, a number of studies have found positive relationship between satisfaction and recommend intention (Brown et al. 2005; Wangenheim and Bayón 2007). Thus, strong evidence supports a positive effect of satisfaction on loyalty intentions. Thus, we propose the following hypotheses:

H5. Satisfaction is positively related to REPINT.

H6. Satisfaction is positively related to RECINT.

As discussed in prior studies (see Keiningham et al. 2015), the notion of a relationship between customer satisfaction and SOW is grounded in the Theory of Planned Behavior (TPB) (Ajzen 1985; 1991), which is an extension of the Theory of Reasoned Action (Ajzen 2001; Ajzen and Fishbein 1980). The original conceptualization of TPB asserts that the effect of attitude on behavior is fully mediated by intention and that there is no direct link between attitude and actual behavior (Conner and Armitage 1998). Nevertheless, a number of researchers have further refined the theory and concluded that in addition to its indirect influence through intention, attitude can influence behavior directly (Bagozzi and Yi 1989; Bentler and Speckart 1981; Liska 1984). In line with these developments, we suggest that satisfaction may directly influence customers' purchasing behavior, measured as their shareof-wallet. Because a large number of studies support this positive relationship (Bowman and 
Narayandas 2004; Cooil et al. 2007; Keiningham, Perkins-Munn, and Evans 2003; Mägi 2003), we present the following hypothesis:

H7. Satisfaction is positively related to SOW.

Customers receive many benefits from engaging in long-term relationships with firms (Berry 1995). These benefits may include confidence, social and special treatment benefits (Gwinner, Gremler, and Bitner 1998), which are positively associated with satisfaction (Hennig-Thurau, Gwinner, and Gremler 2002). Prior studies in the social exchange domain have suggested that consumers aim to maximize their utility or satisfaction when making the decision to share information with a company (Alba et al. 1997; Andrade, Kaltcheva, and Weitz 2002). These studies have shown that consumers actively consider expected benefits and costs of information sharing and that the equilibrium point between the benefits and costs determines the amount of information that customers are willing to share (Rust, Kannan, and Peng 2002). We expect that customers are aware that personal information such as socio-demographic profiles, preferences and purchasing patterns must be shared for them to receive meaningful relationship benefits (Abbott, Stone, and Buttle 2001; Jai and King 2015). Therefore, it is likely that satisfied customers are more willing to share information with a company to obtain relationship benefits. Although previous research has not specifically attempted to model the influence of satisfaction on customers' willingness to provide personal information, we expect that satisfied customers are more likely to share information with companies. Based on the above rationale, we formulate the following hypothesis:

H8. Satisfaction is positively related to WSI.

\section{The impact of willingness to share information on customer loyalty}

As previously mentioned, much research has been conducted on consumers' information disclosure behavior. The majority of these studies adopted a social exchange theory perspective, which offers a framework for examining how individuals' actions are contingent on others' rewarding actions (Emerson 1976). Social exchange theory is based on the assumption that all social life can be treated as exchanges of tangible and intangible rewards and resources between actors (Homans 1961; Zafirovski 2005). As stated by White (2004, 42), "consumers' personal information can be considered a resource insofar as it is unknown 
to marketers (that is, not readily or easily obtained from external sources), yet valued by them. Similarly, the provision of consumers' personal information for marketers' goods, services, or information represents a resource exchange".

Prior studies building on social exchange theory have argued that consumers' willingness to reveal personal information is based on their evaluation of the cost, risk, and benefits (Laufer and Wolfe 1977; Andrade, Kaltcheva, and Weitz 2002). Research has also shown that customers are aware that mutual gain is not present in all relationships and, therefore, are not willing to build relationships and share personal information with unknown organizations (Phelps, Nowak, and Ferrell 2000; Szmigin and Bourne 1998). For example, according to Sheenan and Hoy (2000), consumers' willingness to provide personal information largely depends on the strength of the their relationship with the requesting company. In addition, Lacey and Morgan (2007) report that relational commitment is positively related to customers' WSI with a company. Although little research exists on the effects of customers' WSI on loyalty, we propose that customers who manifest high levels of loyalty intentions and behavior toward the company are familiar with the relational benefits that the company offers (Palmatier et al. 2006; Verma, Sharma, and Sheth 2016) and, therefore, are likely to be more willing to share information with the company to receive those benefits in the future. Hence, the following three hypotheses are posed:

H9. WSI is positively related to SOW.

H10. WSI is positively related to REPINT.

H11. WSI is positively related to RECINT.

\section{The impact of share-of-wallet on loyalty intentions}

Share of wallet may result from inertia, which is often described as habitual behavior (Gounaris and Stathakopoulos 2004; Liu-Thompkins and Tam 2013) and is considered a nonconscious form of human emotion (Huang and $\mathrm{Yu}$ 1999). Typically, inertia has been conceptualized as a single dimensional construct consisting of passive service patronage without true loyalty (Huang and Yu 1999). Much of the early research has provided empirical evidence for habitual behavior (Anderson and Srinivasan 2003; Vogel, Evanschitzky, and Ramaseshan 2008). Prior research has shown that habit or inertia is a strong explanatory factor in models of consumer choice (Jeuland 1979). In addition, previous studies have shown that people's past behavior can have important influences on their future intentions 
(Albarracin and Wyer 2000; Kidwell and Jewell 2003). Therefore, a positive effect of SOW on repurchase intention can be assumed. Furthermore, we expect that SOW may not involve a strong attitudinal component. Therefore, albeit positively related, it has weak effects on recommend intention. Thus, we propose the following hypotheses:

H12: SOW is positively related to REPINT.

H13: SOW is positively related to RECINT.

\section{Control variables}

Customers' loyalty intentions and SOW may also depend on individual and consumption characteristics (Yang and Peterson 2004). With respect to individual characteristics, the model includes gender (Mittal and Kamakura 2001), age (Homburg and Giering 2001), and income (Seiders et al. 2005) as covariates. Prior studies have suggested that customers' consumption characteristics are important determinants of customer loyalty in consumer markets (Rust et al. 2004; Vogel, Evanschitzky, and Ramaseshan 2008). Thus, relationship length (Verhoef 2003 ) is also included as a control variable.

\section{Methodology}

\section{Sample}

The hypotheses were tested by surveying customers in two distinct retail industries (DIY and grocery). Because we used multiple retail categories, similar to Sirdeshmukh, Singh, and Sabol (2002) and Harris and Goode (2004), we can perform a robust test of the hypothesized relationships. Both surveys were completed online. Data collection was conducted in a 14-day period during the summer of 2014. In both cases, a link to the survey was placed on the retailer's home page, and the survey was further advertised in the retailer's monthly newsletter and on the retailer's Facebook page. In total, we received 1,324 valid responses ( $\mathrm{N}=895$ for DIY and $\mathrm{N}=429$ for grocery). Given our data collection method, we calculated the effective response rate by comparing the number of people who opened the survey web page to those who completed and submitted the survey and obtained effective response rates of $58.2 \%$ (DIY) and $63.6 \%$ (grocery). In the DIY sample, the 
majority of the respondents are in the 46-55 (26\%) and 56-65 (26\%) age groups, and the gender distribution is dominated by females (females: 66\% and males: 34\%). Sixty-seven percent of respondents had been customers of the DIY retailer for over three years. Forty-five per cent reported having a household income of 20,001-50,000 (EUR), while 32\% reported an income of 50,001-80,000 (EUR). In the grocery sample, the majority of the respondents are in the 18-25 (26\%) and 26-35 (22\%) age groups, and the gender distribution is dominated by males (females: $31 \%$ and males: 69\%). Seventy-three percent of respondents had been customers of the DIY retailer for one to three years. Thirty-five per cent reported having a household income of 20,000 or less (EUR), while 43\% reported an income of 20,001-50,000 (EUR). The characteristics of both samples are reported in Table 1.

"Insert Table 1 about here"

Nonresponse bias was evaluated by comparing early respondents and late responders in accordance with Armstrong and Overton's (1977) procedure. No significant differences were found between the early and late responders $(p<0.05)$. Thus, nonresponse bias did not significantly affect our results.

Common method bias (CMB) was examined using the Liang et al. (2007) test. It showed that the average variance explained by the indicators (DIY: 0.825; grocery: 0.835 ) is significantly higher than the average method-based variance (DIY: 0.005; grocery: 0.004). Furthermore, in the data collection stage, $\mathrm{CMB}$ was minimized by mixing the items in the questionnaire and keeping the respondents' identities confidential. Thus, common method bias is unlikely to be of serious concern in this study.

\section{Measures}

All measures used in this study were adapted from existing scales. Following similar approaches used in other studies on multiple industries (Harris and Goode 2004; Sirdeshmukh, Singh, and Sabol 2002), we used identical items in the two surveys, and only changes to the firm names and industry names and other minor re-wordings were performed (see Appendix A). All the multi-item scales are based on a reflective measurement scale and are measured on a ten-point scale. 
The perceived value scale was constructed to measure customers' overall assessments of product and service utility based on what is exchanged (Zeithaml 1988). The perceived value measure is often operationalized as customers' responses to a "worth what paid for" question (Gale 1994; Keiningham et al. 2007; Varki and Colgate 2001). In the current study, perceived value was measured with five items concerning price/value for money adapted from Sweeney and Soutar (2001).

Two considerations of the conceptualization of customer satisfaction are worth mentioning. First, we refer to overall satisfaction rather than to any specific facet of service offer. Second, we use a cumulative conceptualization of this construct (Anderson, Fornell, and Lehmann 1994). In other words, we examine the satisfaction level that has developed over time within the retailer-customer relationship rather than satisfaction with a specific service encounter. The scale used in the current study was adapted from Fornell et al. (1996) and included three items.

The repurchase intention scale was designed to gauge the extent to which customers have behavioral intentions to continue buying products at a retail store in the future. It was measured with five items adapted from Lam et al. (2004) and Zeithaml, Berry, and Parasuraman (1996).

In line with Parasuraman, Zeithaml, and Berry (1988), recommend intention was defined as customers' intention to say positive things about the company to others and recommend the company or service to others. It was measured with two items from Zeithaml, Berry, and Parasuraman (1996) and Reichheld (2003).

A share of wallet scale was constructed to measure the percentage of money a customer allocates to a category that is assigned to a specific store (Cooil et al. 2007). It was measured with two items from Wulf, Odekerken-Schröder, and Iacobucci (2001). The first item asked the respondents to indicate the percentage of total category purchases they made at the retailer on a 10 -point scale with $10 \%$ increments $(1=$ less than $10 \%$ to $10=90 \%$ to $100 \%$ ). The second item asked respondents the following question: of the 10 times you select a store to buy [DIY / groceries], how many times do you select this store?

The consumers' WSI scale used in the current study was adapted from the scale of Schoenbacler and Gordon (2002) and included 2 items (10-point scale).

\section{Analyses and results}

The data were first subjected to exploratory factor analysis. Then, the hypotheses were tested with partial least squares structural equation modeling (PLS-SEM) software SmartPLS 
3.0 (Ringle, Wende, and Becker 2014). PLS was chosen for the following two reasons: 1) our interest in predicting the relationships between the target constructs and variance of the outcome variables and 2) PLS is less stringent with non-normal distribution of the data and high correlation of the variables (Hair et al. 2013, 19).

\section{Measurement model}

The evaluation of the reflective constructs shows acceptable reliability and validity, as the factor loadings are all above 0.70 (Table 5) and composite reliabilities are above 0.92 (Table 2). Discriminant validity is formally achieved for all the pairs of constructs, as the square root of AVE exceeds the correlations between the factors (see Table 2). However, the two high correlations $(>0.80)$ between perceived value and satisfaction and between satisfaction and recommend intention indicate that these constructs are closely related.

"Insert Table 2 about here"

PLS does not provide model fit statistics similar to covariance-based SEM; thus, Henseler et al. (2014) suggest that the standardized root mean square residual (SRMR) should be used to evaluate model fit in PLS. Values less than 0.08 are considered a good fit in common factor models. The SRMR value is 0.049 in the DIY study and 0.062 in the grocery study; both of these values are well below the threshold indicating good fit. To summarize, the evaluation of the reflective and formative constructs meets the criteria set in the literature.

The model's predictive relevance is high in terms of repurchase intention and recommend intention. Both $R^{2}$ values are well above 50\% (Table 3) in both studies. For WSI, the $R^{2}$ values are 0.178 (DIY) and 0.255 (grocery), and for SOW, $R^{2}=0.149$ (DIY) and $R^{2}=$ 0.131 (grocery).

\section{Structural model}

The results of the hypothesis testing (direct effects) are shown in Table 3. As indicated, perceived value has positive effects on all outcomes (WSI, SOW, REPINT, RECINT) in both studies, confirming H1-H4. It has the largest effect on REPINT $\left(\beta=0.393, p<0.01 ; f^{2}\right.$ effect size $=0.165)$ in the DIY study and on RECINT $\left(\beta=0.236, p<0.01 ; f^{2}\right.$ effect size $\left.=0.036\right)$ in the grocery study. The results also support $\mathrm{H} 5-\mathrm{H} 8$, as satisfaction has positive effects on all the outcomes in both studies, and the effect size is largest for RECINT in both studies (DIY: $\beta$ $=0.627, p<0.01 ; f^{2}$ effect size $=0.755$; grocery: $\beta=0.390, p<0.01 ; f^{2}$ effect size $\left.=0.094\right)$. 
The direct relationships between WSI and the outcomes are more complicated because WSI has direct positive effects on REPINT (DIY: $\beta=0.198, p<0.01 ; f^{2}$ effect size $=0.084$; grocery: $\beta=0.168, p<0.01 ; f^{2}$ effect size $\left.=0.066\right)$ and RECINT (DIY: $\beta=0.068, p<0.01 ; f^{2}$ effect size $=0.016$; grocery: $\beta=0.167, p<0.01 ; f^{2}$ effect size $\left.=0.054\right)$ in both studies (confirming H10 and H11) but has only a weak effect on SOW in the DIY study (DIY: $\beta=$ $0.078, p<0.05 ; f^{2}$ effect size $=0.009$ ) and no effect on SOW in the grocery study. Thus, H9 is only partially supported.

Finally, in testing H12-H13, we find that SOW is positively related to REPINT in both studies (DIY: $\beta=0.282, p<0.01 ; f^{2}$ effect size $=0.159$; grocery: $\beta=0.390, p<0.01 ; f^{2}$ effect size $=0.392$ ), confirming H12. In line with our expectation that SOW might not exhibit strong effects on RECINT, we find that this relationship is considerably weaker and only confirmed in the grocery study $\left(\beta=0.096, p<0.05 ; f^{2}\right.$ effect size $\left.=0.020\right)$. Thus, H13 is only partially supported.

In terms of the control variables, the only significant effects are those between gender and RECINT (grocery study only), income and RECINT (grocery study only), and relationship length and RECINT (in DIY study only). These findings indicate that males and customers with higher income are more likely to recommend their grocery store to others. With respect to relationship length, in the DIY context, as the length of the relationship increases, the likelihood that customers recommend increases. However, all these effects of the control variables are weak.

Finally, we examined the indirect effects and total effects of our model (see Table 4). Seven of the eight indirect effects are significant in the DIY sample, whereas in the grocery sample, only four of the examined eight indirect relationships are significant. All total effects are significant. These tests shed further light on the hypothesized relationship by showing that a) the effect of perceived value and satisfaction on share of wallet is direct rather than indirect (via WSI), as the indirect effect is small in the DIY sample and not significant in the grocery sample (both VAF values $<0.20$ ); b) the indirect effects of perceived value and satisfaction on repurchase intention are significant, and partial mediation is observed $(0.20<\mathrm{VAF}<$ $0.80)$; c) the indirect effect of perceived value and satisfaction on recommend intention are small, and VAF values less than 0.20 indicate a direct relationship and almost no mediation; and d) the indirect effect of WSI on repurchase intention and recommend intention is not significant or very small. Thus, the effects of WSI on repurchase intention and recommend intention is direct rather than mediated by share of wallet. Thus, we conclude that WSI is an important mediator variable in transferring the effects of perceived value and satisfaction on 
REPINT but has a weak or almost no mediating effect on the relationships between perceived value and SOW, perceived value and RECINT, satisfaction and SOW, and satisfaction and RECINT.

\section{Discussion and conclusion}

The generation and utilization of customer information is a cornerstone of contemporary marketing activities. Customer information gives companies the opportunity to obtain a competitive advantage by developing marketing strategies and tactics aimed at acquiring and maintaining close relationships with customers (Ramani and Kumar 2008). In addition, due to increases in both the amount of data and analysis competence, customer information can be used as an integral part of companies' core offerings: customer data can be converted into information that customers can use in their processes (Saarijärvi, Grönroos, and Kuusela 2014). Paradoxically, as companies become more equipped with better tools to generate and analyze customer data, customers are becoming more suspicious about what companies know and should know about their needs, wants and behavior (Schoenbachler and Gordon 2002). This will not only endanger the creation of new customer relationships but also affect existing and loyal customers as they become more aware of how, why and for the benefit of whom customer data are collected and analyzed. Hence, customers' WSI with companies is a critically important pre-requisite for accumulating a loyal customer base and building successful long-term customer relationships. However, despite its topicality and importance, customers' WSI has remained an underexplored research topic. Based on this observation, this study makes a number of contributions to the literature on retail loyalty and services management.

First, our study is one of the first to examine the effects of perceived value and satisfaction on customers' WSI with a retailer. The results show that perceived value is positively related to WSI. This finding is in the line with previous studies, which have demonstrated that perceived benefits and costs have direct effects on customers' willingness to disclose information (Dinev and Hart 2006; Xu et al. 2009). The results also support our expectation that satisfaction has a significant positive effect on WSI. This finding suggests that in the retailing environment, customers incorporate previous experiences with a firm into their information sharing decisions. Interestingly, our results suggest that perceived value and satisfaction may vary in their relevance in terms of driving WSI across industries. In comparison with satisfaction, perceived value has a stronger influence on WSI in DIY than in grocery retailing. Satisfaction, in turn, has a stronger influence on WSI than does perceived 
value in grocery than in DIY retailing. This finding may reflect the distinct characteristics of retail contexts. It is possible that buying decisions are more complex and of higher cost in DIY retailing, increasing the importance of perceived value. Thus, in DIY retailing, it seems that the information-sharing decision is more rationally based on cost/benefit calculations, with customers estimating their economic gain from sharing information with the retailer. Similarly, it seems that in grocery retailing, customers' information-sharing decision is more emotional in nature, as it is driven by prior positive experiences with the retailer.

Second, consistent with our expectations, we find that WSI has a strong positive effect on loyalty intentions in both retailing contexts. However, the results suggest that WSI has a weak or no effect on SOW in the retailing environment. This finding may reflect consumers' polygamous loyalty behavior toward firms and brands (Dowling and Uncles 1997). That is, consumers typically patronize multiple stores for a variety of products (Meyer-Waarden and Benavent 2009). Moreover, as argued by Bellini, Cardinali, and Ziliani (2011) belonging to loyalty programs does not make customers more loyal as the programs mostly have an influence to already loyal customers. Thus, consumers enroll in multiple loyalty programs to take advantage of all available offers and reward schemes. For instance, the average U.S. household subscribes to 22 different programs; yet, less than half of the memberships per household are active (Berry 2013). Therefore, a customer's WSI with the retailer does not necessarily result in a high SOW.

Third, our results confirm the role of customer perceived value as an antecedent to SOW in retailing. This finding is in line with that of Babakus and Yavas (2008) and highlights the importance of understanding the role of customers' cost/benefits evaluations in their buying behavior. In the retail industry, with its many competing suppliers, perceived value has an especially important influence on customer perceptions and drives store choice and loyalty (Baker et al. 2002; Chaudhuri and Ligas 2009).

Fourth, our results add to a growing body of research that offers support for the positive relationships between satisfaction and SOW across a variety of contexts (Keiningham et al. 2015). A closer look at the relationship reveals that it is weak. This finding is in the line with previous research (Grosso and Castaldo 2015; Hofmeyr et al. 2008; Mägi 2003). The literature proposes several possible explanations for this weak relationship. Researchers have argued that the influence of satisfaction on SOW is nonlinear and asymmetric (Bowman and Narayandas 2004; Keiningham, Perkins-Munn, and Evans 2003). In addition, Hofmeyr and Parton (2010) suggest that customers differ in their sensitivity to variations in satisfaction. Moreover, Keiningham et al. $(2015,2)$ suggest that perceptions are relative and that the 
relationship between satisfaction and SOW is thus mainly driven by "the relative fulfillment customers perceive from the various brands that they use."

Fifth, this research provides empirical evidence that satisfaction is linked with loyalty in the retailing context (Dixon et al. 2005; Grosso \& Castaldo 2015; Nesset, Nervik and Helgesen, 2011) and that there are differences in the effects of satisfaction on repurchase intention and recommend intention. Both of our studies indicate that satisfaction has a stronger effect on recommend intention than on repurchase intention. This finding is in line with that of Watson et al. (2015), who conduct meta-analyses and find that satisfaction has stronger positive effects on attitudinal than on behavioral loyalty. Although recommend intention and repurchase intention are considered attitudinal constructs in this study (Kumar, Dalla Pozza, and Ganesh 2013), it seems that prior positive experiences with a firm are of greater importance for recommend intention than for repurchase intention. This finding reinforces the need to assess and manage the two types of loyalty separately in an attempt to better understand the customer (de Matos and Rossi 2008; Watson et al. 2015).

Sixth, this study shows that SOW positively influences loyalty intentions. Interestingly, we found that SOW has a stronger influence on repurchase intention than on recommend intention. This finding suggests that people's past behavior can significantly influence their future intentions (Albarracin and Wyer 2000; Kidwell and Jewell 2003). Therefore, it might be informative to examine SOW as a predictor of customers' future buying behavior in the retailing context. In addition, it seems that SOW is not a useful proxy for recommend intention.

\section{Managerial implications}

Based on the theoretical contribution addressed above, this study offers several helpful implications for managers. First and foremost, managers should take into account the increasingly important role of customers' WSI for customer relationship management. The study links customers' WSI with constructs that are highly relevant for practitioners, i.e., customer perceived value, satisfaction and customer loyalty. Consequently, managers should extend their focus beyond managing customer relationships to managing customers' WSI.

Second, in addition to identifying the positive relationship between satisfaction and customers' proportion of their overall spending allocated to a particular firm (SOW), our study identifies the significant positive effect of satisfaction on customers' willingness to share information with a retailer. Managers should take into account that satisfaction not only 
drives loyalty but also helps companies develop products and services in the long term because satisfied customers are willing to share information about their purchases and preferences. Consequently, these results clearly indicate that retailers should harness the potential of their satisfied customers when accumulating information from customers. Similarly, customers who perceive that they obtain the most value are also most willing to share information with the retailer, which could be taken into account when the company, for example, is considering which customers to include in new product or service development processes.

Third, managers should take into account that customers' WSI seems to vary across retailing contexts according to perceived value and satisfaction. Consequently, as many retailers operate in multiple retailing areas including, e.g., wholesaling, DIY, groceries, or car retailing, companies should consider the different characteristics of each retail category when assessing customers' WSI. Furthermore, although not addressed in this study, a similar difference may be found between different retail formats, e.g., hypermarket, supermarket, convenience stores, and hard discounters. However, this must be empirically verified, thus representing an interesting avenue for future research.

Conclusively, to personalize their services and better serve their customers, managers have to ensure that customers are willing to share information regarding their behavior and preferences. This exerts pressure to gain an understanding of the determinants of customers' WSI. In addition, the cost of avoiding the issue of information sharing is high. For instance, inaccurate data of the U.S. economy resulted in unnecessary postage, printing and staff overhead, costing approximately six hundred billion dollars per year. In addition, most companies that use CRM systems cannot create accurate customer profiles due to insufficient data, decreasing their ability to personalize their services (Poddar, Donthu, and Wei 2009). Thus, companies should not take for granted customers' WSI with them. In that respect, to ensure the quality of their database, companies must build trust to increase customers' WSI (Schoenbachler and Gordon 2002). Customers' positive experience of sharing information can become a critically important antecedent of a future successful relationship. Furthermore, companies should also consider the role and potential of customer data in a more customercentric manner. It is important for customers to believe that the information is used in a manner that benefits them in the future. If companies do not consider the value creation for both their customers and themselves, companies may lose access to the customer data required (Saarijärvi, Karjaluoto, and Kuusela 2013). 


\section{Limitations and future research}

Similar to the findings of any empirical research, the results of the present study cannot be interpreted without taking into account the study's limitations. Furthermore, this study also points to some interesting avenues for future research. First, we used self-reported loyalty data rather than actual SOW data. While this method is commonly used in the SOW literature (Hunneman, Verhoef, and Sloot 2014; Keiningham et al. 2014a), we must recognize that these data may be biased and that the reported correlations might be too high. Additionally, we measured perceived value from a cost-benefit perspective. Thus, future studies could measure perceived value using multiple items to capture its broader domain (Sweeney and Soutar 2001) and achieve sound psychometric properties. Similarly, the WSI measure can be complemented by additional items, such as privacy concern, trust, and type of data. Furthermore, given that customer satisfaction is relative to competitive alternatives (Keiningham et al. 2014b; Varki and Rust 1997), the use of relative measures of satisfaction when testing the effects of satisfaction on share-of-wallet (Keiningham et al. 2015; Mägi 2003) and WSI may provide insights.

Second, because this study focuses on only two industries, groceries and DIY, it has limited generalizability. Although these industries are quite diverse and represent both durable and non-durable goods, the findings would benefit from inquiries in other service industry settings. Furthermore, this study utilized data only from business-to-consumer relationships. Thus, replication of the study in business-to-business contexts is desirable. Similar studies should also be conducted in other countries to understand the role of culture in customers' information-sharing behavior. Also it should be noted that contemporary retailing is shifting increasingly toward omni-channel retailing, i.e. retailers operating in both online and offline channels with the aim of creating a seamless customer experience across channels. This obviously has major implications on what kind of data (e.g. pos-data, web browsing data, online shopping cart data, location data, etc.) is collected and how it is stored, utilized, and integrated between all channels, and consequently, how the evolving nature of customer data management may influence customers' WSI.

Third, we focused on a limited number of antecedents of customers' WSI. Although the two antecedents studied are rather important, future studies could include a wider range of constructs to broaden the scope of the model and help distinguish both conceptual and empirical associations between constructs. For example, customers' privacy concerns would still certainly add important additional insight in explaining customers' WSI. Furthermore, as 
discussed above, including different types of customer data, i.e. what kind of data customers are sharing (e.g. traditional demographics vs. point-of-sale data) could provide complementary understanding of the phenomenon. Consequently, customers' WSI can vary between business contexts: customers can be more sensitive about sharing financial or medical data than their shopping history from the DIY context. Therefore, additional empirical studies need to be conducted to understand these contextual differences, which would provide important insights about customers' WSI, and perhaps uncover new perspectives on how customers eventually perceive these businesses.

Finally, this study relied on cross-sectional data. Longitudinal data might improve our understanding of the mechanisms underlying the effects. Researchers pursuing such avenues may both effectively extend the foundational research of this study and provide innovative approaches to a rapidly changing marketplace.

\section{References}

Abbott, J., Stone, M., and Buttle, F. 2001. "Customer Relationship Management in Practice A Qualitative Study.” The Journal of Database Marketing 9 (1): 24-34.

Adams, J.S. 1963. "Towards an Understanding of Inequity." The Journal of Abnormal and Social Psychology 67 (5): 422.

Adams, J.S. 1965. "Inequity in Social Exchange." in Advances in Experimental Social Psychology (Vol. 2), edited by L. Berkowitz, 267-299. New York: Academic press.

Ajzen, I. 1985. "From Intentions to Actions: A Theory of Planned Behavior.", Action

Control: From Cognition to Behavior, edited by J. Kuhl and J. Beckmann, 11-39. New York: Springer Verlag.

Ajzen, I. 1991. "The Theory of Planned Behavior.” Organizational Behavior and Human Decision processes 50 (2): 179-211.

Ajzen, I. 2001. "Nature and Operation of Attitudes." Annual Review of Psychology 52 (1): 27-58.

Ajzen, I., and Fishbein M. 1980. Understanding Attitudes and Predicting Social Behavior. NJ, Englewood Cliffs: Prentice-Hall.

Alba, J. Lynch, J. Weitz, B.A., Janiszewski, C., Lutz, R., Sawyer, A., and Woods, S. 1997. "Interactive Home Shopping: Consumer, Retailer, and Manufacturers Incentives to Participate in Electronic Markets.” Journal of Marketing 61 (3): 38-53. 
Albarracin, D., and Wyer Jr, R.S. 2000. "The Cognitive Impact of Past Behavior: Influences on Beliefs, Attitudes, and Future Behavioral Decisions." Journal of Personality and Social Psychology 79 (1): 5-22.

Andrade, E.B., Kaltcheva, V.D., and Weitz, B.A 2002. "Self-Disclosure on the Web: The Impact of Privacy Policy, Reward, and Company Reputation." Advances in Consumer Research 29 (1): 350-353.

Anderson, E.W., Fornell, C., and Lehmann, D.R. 1994. "Customer Satisfaction, Market Share, and Profitability: Findings from Sweden.” Journal of Marketing 58 (3): 53-66.

Anderson, R.E., and Srinivasan, S.S. 2003. "E-Satisfaction and e-Loyalty: A Contingency Framework." Psychology \& Marketing 20 (2): 123-138.

Armstrong, J.S., and Overton, T.S. 1977. "Estimating Nonresponse Bias in Mail Surveys." Journal of Marketing Research 14 (3): 396-402.

Babakus, E., and Yavas, U. 2008. "Does Customer Sex Influence the Relationship Between Perceived Quality and Share of Wallet?” Journal of Business Research 61 (9): 974981.

Bagozzi, R.P. 1975. “Marketing as Exchange.” Journal of Marketing 39 (4): 32-39.

Bagozzi, R.P., and Yi, Y. 1989. "The Degree of Intention Formation as a Moderator of the Attitude-Behavior Relationship.”Social Psychology Quarterly 52 (4): 266-279.

Bansal, G., Zahedi, F., and Gefen, D. 2015. "The Role of Privacy Assurance Mechanisms in Building Trust and the Moderating Role of Privacy Concern." European Journal of Information Systems 24 (6): 624-644.

Baker, J., Parasuraman, A., Grewal, D., and Voss, G.B. 2002. "The Influence of Multiple Store Environment Cues on Perceived Merchandise Value and Patronage Intentions." Journal of Marketing 66 (2): 120-141.

Bellini, S., Cardinali, M.G., and Ziliani, C. 2011. "Building Customer Loyalty in Retailing: Not All Levers are Created Equal." The International Review of Retail, Distribution and Consumer Research 21 (5): 461-481.

Bentler, P.M., and Speckart, G. 1981. "Attitudes "Cause” Behaviors: A Structural Equation Analysis." Journal of Personality and Social Psychology 40 (2): 226-238.

Berry, L.L. 1995. "Relationship Marketing of Services - Growing Interest, Emerging Perspectives." Journal of the Academy of Marketing Science 23 (4): 236-245.

Berry, J. 2013. "Bulking Up: The 2013 COLLOQUY Loyalty Census - Growth and Trends in U.S. Loyalty Program Activity." COLLOQUYtalk, June, 1-13. 
Bolton, R.N., and Lemon, K.N. 1999. “A Dynamic Model of Customers’ Usage of Services: Usage as an Antecedent and Consequence of Satisfaction." Journal of Marketing Research 36 (2): 171-186.

Bolton, R.N., Kannan, P.K., and Bramlett, M.D. 2000. "Implications of Loyalty Program Membership and Service Experiences for Customer Retention and Value." Journal of the Academy of Marketing Science 28 (1): 95-108.

Bowman, D., and Narayandas, D. 2004. "Linking Customer Management Effort to Customer Profitability in Business Markets.” Journal of Marketing Research 41 (4): 433-447.

Brodie, R.J., Whittome, J.R., and Brush, G.J. 2009. "Investigating the Service Brand: A Customer Value Perspective." Journal of Business Research 62 (3): 345-355.

Brown, T.J., Barry, T.E., Dacin, P.A., and Gunst, R.F. 2005. "Spreading the Word: Investigating Antecedents of Consumers' Positive Word-of-Mouth Intentions and Behaviors in a Retailing Context.” Journal of the Academy of Marketing Science 33 (2): $123-138$.

Carrell, M.R., and Dittrich, J.E. 1978. "Equity Theory: The Recent Literature, Methodological Considerations, and New Directions." Academy of Management Review 3 (2): 202210.

Chandon, P., Morwitz, V.G., and Reinartz, W.J. 2005. "Do Intentions Really Predict Behavior? Self-Generated Validity Effects in Survey Research.” Journal of Marketing 69 (2): 1-14.

Chaudhuri, A., and Ligas, M. 2009. "Consequences of Value in Retail Markets.” Journal of Retailing 85 (3): 406-419.

Cooil, B., Keiningham, T.L., Aksoy, L., and Hsu, M. 2007. “A Longitudinal Analysis of Customer Satisfaction and Share of Wallet: Investigating the Moderating Effect of Customer Characteristics." Journal of Marketing 71 (1): 67-83.

Conner, M., and Armitage, C.J. 1998. "Extending the Theory of Planned Behavior: A Review and Avenues for Further Research.” Journal of Applied Social Psychology 28 (15): $1429-1464$.

de Matos, C.A., and Rossi, C.A.V. 2008. "Word-of-Mouth Communications in Marketing: A Meta-Analytic Review of the Antecedents and Moderators." Journal of the Academy of Marketing Science 36 (4): 578-596.

Derlega, V.J., Barbara A. Winstead, A.M., and Braitman, A.L. 2008. "Why Does Someone Reveal Highly Personal Information? Attributions For and Against Self-disclosure in Close Relationships.” Communications Research Reports 25 (2): 115-130. 
Dinev, T., and Hart, P. 2006. “An Extended Privacy Calculus Model for E-Commerce Transactions." Information Systems Research 17 (1): 61-80.

Dixon, J., Bridson, J., Evans, J., and Morrison, M. 2005. “An Alternative Perspective on Relationships, Loyalty and Future Store Choice." The International Review of Retail, Distribution and Consumer Research 15 (4): 351-374.

Dowling, G.R., and Uncles M. 1997. “Do Customer Loyalty Programs Really Work?” MIT Sloan Management Review 38 (4): 71-82.

Eggert, A., and Ulaga, W. 2010. "Managing Customer Share in Key Supplier Relationships.” Industrial Marketing Management 39 (8): 1346-1355.

Emerson, R.M. 1976. “Social Exchange Theory.” Annual Review of Sociology 2: 335-362.

Fornell, C., Johnson, M.D., Anderson, E.W., Cha, J., and Bryant, B.E. 1996. "The American Customer Satisfaction Index: Nature, Purpose, and Findings." The Journal of Marketing 60 (4): 7-18.

Friedman, D.C., Brown, T.A., and Taran, Z. 2011. "Specialty Store Expertise as a Driver of Satisfaction and Share of Wallet." The International Review of Retail, Distribution and Consumer Research 21 (4): 375-389.

Gale, B.T. 1994. Managing Customer Value. NY: The Free Press.

Garbarino, E., and Johnson, M.S. 1999. "The Different Roles of Satisfaction, Trust, and Commitment in Customer Relationships.” Journal of Marketing 63 (2): 70-87.

Gounaris, S., and Stathakopoulos, V. 2004. "Antecedents and Consequences of Brand Loyalty: An Empirical Study.” Journal of Brand Management 11 (4): 283-306.

Greenaway, K., Chan, Y.E., and Crossler, R.E. 2015. “Company Information Privacy Orientation: A Conceptual Framework.” Information Systems Journal 25 (6): 579606.

Grewal, D., Monroe, K.B., and Krishnan, R. 1998. “The Effects of Price-Comparison Advertising on Buyers' Perceptions of Acquisition Value, Transaction Value, and Behavioral Intentions." Journal of Marketing 62 (2): 46-59.

Grosso, M., and Castaldo, S. 2015. “How Store Attributes Impact Shoppers’ Loyalty: Do Different National Cultures Follow the Same Loyalty Building Process?” The International Review of Retail, Distribution and Consumer Research 25 (5): 503-515.

Gruen, T.W., Osmonbekov, T., and Czaplewski, A.J. 2006. "eWOM: The Impact of Customer-to-Customer Online Know-How Exchange on Customer Value and Loyalty." Journal of Business Research 59 (4): 449-456. 
Gwinner, K.P., Gremler, D.D., and Bitner, M.J. 1998. "Relational Benefits in Services Industries: The Customer's Perspective." Journal of the Academy of Marketing Science 26 (2): 101-114.

Hair, J.F.Jr., Hult, G.T.M., Ringle, C.M., and Sarstedt, M. 2013. A Primer on Partial Least Squares Structural Equation Modeling (PLS-SEM). LA: Sage.

Harris, L.C., and Goode, M.M. 2004. "The Four Levels of Loyalty and the Pivotal Role of Trust: A Study of Online Service Dynamics.” Journal of Retailing 80 (2): 139-158.

Hartline, M.D., and Jones, K.C. 1996. "Employee Performance Cues in a Hotel Service Environment: Influence on Perceived Service Quality, Value, and Word-of-Mouth Intentions." Journal of Business Research 35 (3): 207-215.

Hennig-Thurau, T., Gwinner, K.P., and Gremler, D.D. 2002. "Understanding Relationship Marketing Outcomes an Integration of Relational Benefits and Relationship Quality.” Journal of Service Research 4 (3): 230-247.

Henseler, J., Dijkstra, T.K., Sarstedt, M., Ringle, C.M., Diamantopoulos, A., Straub, D.W., Ketchen Jr., D.J., Hair, J.F., Hult, G.T.M., and Calantone, R. (2014), “Common Beliefs and Reality About PLS. Comments on Rönkkö and Evermann (2013).” Organizational Research Methods 17 (2): 182-209.

Hofmeyr, J., Goodall, V., Bongers, M., and Holtzman, P. 2008. “A New Measure of Brand Attitudinal Equity Based on the Zipf Distribution." International Journal of Market Research 50 (2): 181-202.

Hofmeyr, J., and Parton, G. 2010. "Rank Matters." Marketing Research 22 (3): 6-12.

Holbrook, M.B. 1994. "The Nature of Customer Value: An Axiology of Services in the Consumption Experience." Service Quality: New Directions in Theory and Practice, edited by R.T. Rust and R.L. Oliver, 21-71. Thousand Oaks, CA: Sage Publications.

Homans, G.C. 1961. Social Behavior: Its Elementary Forms. NY: Harcourt, Brace \& World. Homburg, C., and Giering, A. 2001. "Personal Characteristics as Moderators of the Relationship Between Customer Satisfaction and Loyalty - An Empirical Analysis.” Psychology \& Marketing 18 (1): 43-66.

Huang, M.H., and Yu, S. 1999. “Are Consumers Inherently or Situationally Brand Loyal?-A Set Intercorrelation Account for Conscious Brand Loyalty and Nonconscious Inertia.” Psychology \& Marketing 16 (6): 523-544.

Hughes, D.E., Le Bon, J., and Rapp, A. 2013. “Gaining and Leveraging Customer-Based Competitive Intelligence: The Pivotal Role of Social Capital and Salesperson 
Adaptive Selling Skills.” Journal of the Academy of Marketing Science 41 (1): 91110.

Hunneman, A., Verhoef, P.C., and Sloot, L.M. 2015. "The Impact of Consumer Confidence on Store Satisfaction and Share of Wallet Formation." Journal of Retailing 91 (3): $516-532$.

Jai, T-M., and King, N.J. 2015. "Privacy Versus Reward: Do Loyalty Programs Increase Consumers' Willingness to Share Personal Information with Third-Party Advertisers and Data Brokers.” Journal of Retailing and Consumer Services 28 (1): 296-303. Jayachandran, S., Sharma, S., Kaufman, P., and Raman, P. 2005. "The Role of Relational Information Processes and Technology Use in Customer Relationship Management." Journal of Marketing 69 (3): 177-192.

Jeuland, A.P. 1979. "Brand Choice Inertia as One Aspect of the Notion of Brand Loyalty." Management Science 25 (7): 671-682.

John, L.K., Acquisti, A., and Loewenstein, G. 2011. "Strangers on a Plane: ContextDependent Willingness to Divulge Sensitive Information." Journal of Consumer Research 37 (5): 858-873.

Keiningham, T.L., Perkins-Munn, T., and Evans, H. 2003. "The Impact of Customer Satisfaction on Share-of-Wallet in a Business-to-Business Environment." Journal of Service Research 6 (1): 37-50.

Keiningham, T.L., Cooil, B., Aksoy, L., Andreassen, T.W., and Weiner, J. 2007. "The Value of Different Customer Satisfaction and Loyalty Metrics in Predicting Customer Retention, Recommendation, and Share-of-Wallet.” Managing Service Quality 17 (4): $361-384$

Keiningham, T.L., Aksoy, L., C. Malthouse, E., Lariviere, B., and Buoye, A. 2014a. "The Cumulative Effect of Satisfaction with Discrete Transactions on Share of Wallet." Journal of Service Management 25 (3): 310-333.

Keiningham, T.L., Gupta, S., Aksoy, L., and Buoye, A. 2014b. "The High Price of Customer Satisfaction.” MIT Sloan Management Review 55 (3): 37-46.

Keiningham, T.L., Cooil, B., Malthouse, E.C., Buoye, A., Aksoy, L., De Keyser, A., and Lariviere, B. 2015. "Perceptions Are Relative: An Examination of the Relationship Between Relative Satisfaction Metrics and Share of Wallet.” Journal of Service Management 26 (1): 2-43. 
Kidwell, B., and Jewell, R.D. 2003. "The Moderated Influence of Internal Control: An Examination Across Health-Related Behaviors.” Journal of Consumer Psychology 13 (4): $377-386$.

Kumar, V., and Reinartz, W. 2012. Customer Relationship Management: Concept, Strategy, and Tools. Berlin: Springer.

Kumar, V., Dalla Pozza, I., and Ganesh, J. 2013. "Revisiting the Satisfaction-Loyalty Relationship: Empirical Generalizations and Directions for Future Research.” Journal of Retailing 89 (3): 246-262.

Lacey, R., and Morgan, R.M. 2007. "Committed Customers as Strategic Marketing Resources.” Journal of Relationship Marketing 6 (2): 51-65.

Lam, S.Y., Shankar, V., Erramilli, M.K., and Murthy, B. 2004. "Customer Value, Satisfaction, Loyalty, and Switching Costs: An Illustration from a Business-toBusiness Service Context." Journal of the Academy of Marketing Science 32 (3): 293311.

Laufer, R.S., and Wolfe, M. 1977. "Privacy as a Concept and a Social Issue: A Multidimensional Developmental Theory.” Journal of Social Issues 33 (3): 22-42.

Liang, H., Saraf, N., Hu, Q., and Xue, Y. 2007. “Assimilation of Enterprise Systems: The Effect of Institutional Pressures and the Mediating Role of Top Management." MIS Quarterly 31 (1): 59-87.

Liska, A.E. 1984. "A Critical Examination of the Causal Structure of the Fishbein/Ajzen Attitude-Behavior Model." Social Psychology Quarterly 47 (1): 61-74.

Liu-Thompkins, Y., and Tam, L. 2013. "Not All Repeat Customers Are the Same: Designing Effective Cross-Selling Promotion on the Basis of Attitudinal Loyalty and Habit." Journal of Marketing 77 (5): 21-36.

McKee, D., Simmers, C.S., and Licata, J. 2006. "Customer Self-Efficacy and Response to Service.” Journal of Service Research 8 (3): 207-220.

Metzger, M. J. 2004. "Privacy, Trust, and Disclosure: Exploring Barriers to Electronic Commerce." Journal of Computer-Mediated Communication 9 (4): DOI: 10.1111/j.1083-6101.2004.tb00292.x

Metzger, M.J. 2006. "Effects of Site, Vendor, and Consumer Characteristics on Web Site Trust and Disclosure." Communication Research 33 (3): 155-179.

Meyer-Waarden, L., and Benavent, C. 2009. "Grocery Retail Loyalty Program Effects: SelfSelection or Purchase Behavior Change?" Journal of the Academy of Marketing Science 37 (3): 345-358. 
Miceli, G., Raimondo, M.A., and Farace, S. 2013. "Customer Attitude and Dispositions Towards Customized Products: The Interaction Between Customization Model and Brand." Journal of Interactive Marketing 27 (3): 209-225.

Milne, G.R., and Culnan, M.J. 2002. "Using the Content of Online Privacy Notices to Inform Public Policy: A Longitudinal Analysis of the 1998-2001 U.S. Web Surveys.” The Information Society 18 (5): 345-359.

Milne, G.R., and Culnan, M.J. 2004. "Strategies for Reducing Online Privacy Risks: Why Consumers Read (or Don't' Read) Online Privacy Notices.” Journal of Interactive Marketing 18 (3): 15-29.

Mittal, V., and Kamakura, W.A. 2001. "Satisfaction, Repurchase Intent, and Repurchase Behavior: Investigating the Moderating Effect of Customer Characteristics." Journal of Marketing Research 38 (1): 131-142.

Mothersbaugh, D.L., Foxx, W.K., Beatty, S.E., and Wang, S. 2012. "Disclosure Antecedents in an Online Service Context: The Role of Sensitivity of Information.” Journal of Service Research 15 (1): 76-98.

Mägi, A.W. 2003. "Share of Wallet in Retailing: The Effects of Customer Satisfaction, Loyalty Cards and Shopper Characteristics.” Journal of Retailing 79 (2): 97-106.

Nesset, E., Nervik, B., and Helgesen, Ø. 2011. "Satisfaction and Image as Mediators of Store Loyalty Drivers in Grocery Retailing." The International Review of Retail, Distribution and Consumer Research 21 (3): 267-292.

Oliver, R.L. 1993. "Cognitive, Affective, and Attribute Bases of the Satisfaction Response.” Journal of Consumer Research 20 (3): 418-430.

Oliver, R.L., and DeSarbo, W.S. 1988. "Response Determinants in Satisfaction Judgments." Journal of Consumer Research 14 (4): 495-507.

Olivero, N., and Lunt, P. 2004. "Privacy Versus Willingness to Disclose in E-Commerce Exchanges: The Effect of Risk Awareness on the Relative Role of Trust and Control." Journal of Economic Psychology 25 (2): 243-262.

Palmatier, R.W., Dant, R.P., Grewal, D., and Evans, K.R. 2006. "Factors Influencing the Effectiveness of Relationship Marketing: A Meta-Analysis.” Journal of Marketing 70 (4): 136-153.

Parasuraman, A., Zeithaml, V.A., and Berry, L.L. 1988. "SERVQUAL: A Multiple-Item Scale for Measuring Consumer Perceptions of Service Quality.” Journal of Retailing 64 (1): $12-40$. 
Poddar, A., Donthu, N., and Wei, Y. 2009. "Web Site Customer Orientations, Web Site Quality, and Purchase Intentions: The Role of Web Site Personality.” Journal of Business Research 62 (4): 441-450.

Pfeifer, P.E., and Ovchinnikov, A. 2011. "A Note on Willingness to Spend and Customer Lifetime Value for Firms with Limited Capacity”, Journal of Interactive Marketing 25 (3): 178-189.

Phelps, J., Nowak, G., and Ferrell, E. 2000. "Privacy Concerns and Consumer Willingness to Provide Personal Information.” Journal of Public Policy \& Marketing 19 (1): 27-41.

Premazzi, K., Castaldo, S., Grosso, M., Raman, P., Brudvig, S., and Hofacker, C.F. 2010. "Customer Information Sharing with E-Vendors: The Roles of Incentives and Trust." International Journal of Electronic Commerce 14 (3): 63-91.

Ramani, G., and Kumar V. 2008. "Interaction Orientation and Firm Performance.” Journal of Marketing 72 (1): 27-45.

Reichheld, F.F. 2003. "The One Number You Need to know.” Harvard Business Review 81 (12): 46-55.

Richards, K.A., and Jones, E. 2008. "Customer Relationship Management: Finding Value Drivers.” Industrial Marketing Management 37 (2): 120-130.

Ringle, C.M., Wende, S., and Becker, J-M. 2014. "SmartPLS 3", available at: http://www.smartpls.com (accessed 20 August 2015).

Rintamäki, T., Kanto, A., Kuusela, H., and Spence, M.T. 2006. "Decomposing the Value of Department Store Shopping into Utilitarian, Hedonic and Social Dimensions: Evidence from Finland." International Journal of Retail \& Distribution Management 34 (1): 6-24.

Rust, R.T, Kannan, P., and Peng, N. 2002. "The Customer Economics of Internet Privacy." Journal of the Academy of Marketing Science 30 (4): 455-464.

Rust, R.T., Ambler, T., Carpenter, G.S., Kumar, V., and Srivastava R.K. 2004. "Measuring Marketing Productivity: Current Knowledge and Future Direction.” Journal of Marketing 68 (4): 76-89.

Saarijärvi, H, Grönroos, C., and Kuusela, H. 2014. "Reverse Use of Customer Data: Implications for Service-Based Business Models.” Journal of Services Marketing 27 (7): 529-537.

Saarijärvi, H., Karjaluoto, H., and Kuusela, H. 2013. "Customer Relationship Management: The Evolving Role of Customer Data." Marketing Intelligence \& Planning 31 (6): $584-600$. 
Samaha, S.A., Palmatier, R.W., and Dant, R.P. 2011. "Poisoning Relationships: Perceived Unfairness in Channels of Distribution.” Journal of Marketing 75 (3): 99-117.

Schoenbachler, D.D., and Gordon, G.L. 2002. "Trust and Customer Willingness to Provide Information in Database-Driven Relationship Marketing." Journal of Interactive Marketing 16 (3): 2-16.

Seiders, K., Voss, G.B., Grewal, D., and Godfrey, A.L. 2005. "Do Satisfied Customers Buy More? Examining Moderating Influences in a Retailing Context.” Journal of Marketing 69 (4): 26-43.

Shankar, V., Smith, A.K., and Rangaswamy, A. 2003. "Customer Satisfaction and Loyalty in Online and Offline Environments." International Journal of Research in Marketing 20 (2): 153-175.

Sheehan, K.B., and Hoy, M.G. 2000. "Dimensions of Privacy Concern Among Online Consumers.” Journal of Public Policy \& Marketing 19 (1): 62-73.

Sirdeshmukh, D., Singh, J., and Sabol, B. 2002. "Consumer Trust, Value, and Loyalty in Relational Exchanges." Journal of Marketing 66 (1): 15-37.

Steinhoff, L., and Palmatier, R.W. 2016. "Understanding Loyalty Program Effectiveness: Managing Target and Bystander Effects." Journal of the Academy of Marketing Science 44 (1): 88-107.

Sweeney, J.C., and Soutar, G.N. 2001. "Consumer Perceived Value: The Development of a Multiple Item Scale.” Journal of Retailing 77 (2): 203-220.

Szmigin, I., and Bourne, H. 1998. "Consumer Equity in Relationship Marketing.” Journal of Consumer Marketing 15 (6): 544-557.

Söderlund, M. 2006. "Measuring Customer Loyalty with Multi-Item Scales: A Case for Caution." International Journal of Service Industry Management 17 (1): 76-98.

Thaler, R. 1985. "Mental Accounting and Consumer Choice.” Marketing Science 4 (3): 199214.

Thaler, R.H., and Johnson, E.J. 1990. "Gambling with the House Money and Trying to Break Even: The Effects of Prior Outcomes on Risky Choice.” Management Science 36 (6): 643-660.

Tse, D.K., and Wilton, P.C. 1988. "Models of Consumer Satisfaction Formation: An Extension." Journal of Marketing Research 25 (2): 204-212.

Varki, S., and Colgate, M. 2001. "The Role of Price Perceptions in an Integrated Model of Behavioral Intentions." Journal of Service Research 3 (3): 232-240. 
Varki, S., and Rust, R.T. 1997. "Satisfaction Is Relative: Apply Analysis of Variance Techniques to Determine if Your CSM Scores Measure Up.” Marketing Research, 9 (Summer): 15-19.

Verhoef, P.C. 2003. "Understanding the Effect of Customer Relationship Management Efforts on Customer Retention and Customer Share Development.” Journal of Marketing 67 (4): $30-45$.

Verhoef, P.C., Kannan, P.K., and Inman, J.J. 2015. "From Multi-Channel Retailing to OmniChannel Retailing: Introduction to the Special Issue on Multi-Channel Retailing.” Journal of Retailing 91 (2): 174-181.

Verma, V., Sharma, D., and Sheth, J. 2016. "Does Relationship Marketing Matter in Online Retailing? A Meta-Analytic Approach.” Journal of the Academy of Marketing Science 44 (2): 206-217.

Vogel, V., Evanschitzky, H., and Ramaseshan, H. 2008. “Customer Equity Drivers and Future Sales." Journal of Marketing 72 (6): 98-108.

Wang, S., Beatty, S.E., and Foxx, W. 2004. "Signaling the Trustworthiness of Small Online Retailers." Journal of Interactive Marketing 18 (1): 53-69.

Wangenheim, F.V., and Bayón, T. 2007. "Behavioral Consequences of Overbooking Service Capacity." Journal of Marketing 71 (4): 36-47.

Watson, G.F., Beck, J.T., Henderson, C.M., and Palmatier, R.W. 2015. "Building, Measuring, and Profiting from Customer Loyalty." Journal of the Academy of Marketing Science 43 (6): 790-825.

White, T.B. 2004. "Consumer Disclosure and Disclosure Avoidance: A Motivational Framework." Journal of Consumer Psychology 14 (1): 41-51.

White, T.B., Novak, T.P., and Hoffman, D.L. 2014. "No Strings Attached: When Giving It Away Versus Making Them Pay Reduces Consumer Information Disclosure.” Journal of Interactive Marketing 28 (3): 184-195.

Wu, K.-W., Huang, S.Y., Yen, D.C., and Popova, I. 2012. "The Effect of Online Privacy Policy on Consumer Privacy Concern and Trust." Computers in Human Behavior 28 (3): 889-897.

Wulf, K.D., Odekerken-Schröder, G., and Iacobucci, D. 2001. "Investments in Consumer Relationships: A Cross-Country and Cross-Industry Exploration.” Journal of Marketing 65 (4): $33-50$

Yang, Z., and Peterson, R.T. 2004. "Customer Perceived Value, Satisfaction, and Loyalty: The Role of Switching Costs.” Psychology \& Marketing 21 (10): 799-802. 
Xu, H., Teo, H.H., Tan, B.C., and Agarwal, R. 2009. "The Role of Push-Pull Technology in Privacy Calculus: The Case of Location-Based Services." Journal of Management Information Systems 26 (3): 135-174.

Zafirovski, M. 2005. "Social Exchange Theory Under Scrutiny: A Positive Critique of Its Economic-Behaviorist Formulations.” Electronic Journal of Sociology 2 (2): 1-40. Zeithaml, V.A. 1988. “Consumer Perceptions of Price, Quality, and Value: A Means-End Model and Synthesis of Evidence.” Journal of Marketing 52 (3): 2-22.

Zeithaml, V.A., Berry, L.L., and Parasuraman, A. 1996. "The Behavioral Consequences of Service Quality.” Journal of Marketing 60 (2): 31-46. 


\section{LIST OF TABLES}

Table 1. Profile of the respondents

\begin{tabular}{|c|c|c|c|c|}
\hline & \multicolumn{2}{|c|}{ DIY } & \multicolumn{2}{|c|}{ Grocery } \\
\hline & $\mathrm{N}$ & $\%$ & $\mathrm{~N}$ & $\%$ \\
\hline \multicolumn{5}{|l|}{ Gender } \\
\hline Female & 587 & 65.6 & 132 & 30.8 \\
\hline Male & 308 & 34.4 & 297 & 69.2 \\
\hline Total & 895 & 100 & 429 & 100 \\
\hline \multicolumn{5}{|l|}{ Age } \\
\hline $18-25$ & 33 & 3.7 & 112 & 26.1 \\
\hline $26-35$ & 133 & 14.9 & 93 & 21.7 \\
\hline $36-45$ & 167 & 18.7 & 75 & 17.5 \\
\hline $46-55$ & 228 & 25.5 & 90 & 21.0 \\
\hline $56-65$ & 235 & 26.3 & 44 & 10.3 \\
\hline 66 or more & 99 & 11.1 & 15 & 3.5 \\
\hline Total & 895 & 100 & 429 & 100 \\
\hline \multicolumn{5}{|c|}{ Income (household gross EUR) } \\
\hline Below 20,000 & 84 & 9.4 & 149 & 34.7 \\
\hline $20,001-50,000$ & 398 & 44.5 & 183 & 42.7 \\
\hline $50,001-80,000$ & 289 & 32.3 & 73 & 17.0 \\
\hline 80,001 or more & 124 & 13.9 & 24 & 5.6 \\
\hline Total & 895 & 100 & 429 & 100 \\
\hline \multicolumn{5}{|l|}{ Relationship length } \\
\hline Less than six months & 66 & 7.3 & 22 & 5.1 \\
\hline 6-12 months & 20 & 2.2 & 43 & 10.0 \\
\hline $1-3$ years & 211 & 23.6 & 315 & 73.4 \\
\hline Over 3 years & 598 & 66.8 & 49 & 11.4 \\
\hline Total & 895 & 100 & 429 & 100 \\
\hline
\end{tabular}


Table 2: Discriminant validity, composite reliability, means and standard deviations

\begin{tabular}{|c|c|c|c|c|c|c|c|c|c|c|c|c|}
\hline & $\overline{A V E}$ & $\mathrm{CR}^{\mathrm{a}}$ & (1) & (2) & (3) & (4) & (5) & (6) & (7) & (8) & (9) & $(10)$ \\
\hline PEVA (1) & $\begin{array}{c}0.871 \\
(0.868)\end{array}$ & $\begin{array}{c}0.971 \\
(0.970)\end{array}$ & $\begin{array}{c}0.933 \\
(0.932)\end{array}$ & & & & & & & & & \\
\hline WSI (2) & $\begin{array}{c}0.898 \\
(0.932)\end{array}$ & $\begin{array}{c}0.796^{\mathrm{c}} \\
(0.710)^{\mathrm{c}}\end{array}$ & $\begin{array}{c}0.410 \\
(0.433)\end{array}$ & $\begin{array}{c}0.948 \\
(0.965)\end{array}$ & & & & & & & & \\
\hline SAT (3) & $\begin{array}{c}0.871 \\
(0.876)\end{array}$ & $\begin{array}{c}0.953 \\
(0.955)\end{array}$ & $\begin{array}{c}0.746 \\
(0.857)\end{array}$ & $\begin{array}{c}0.374 \\
(0.446)\end{array}$ & $\begin{array}{c}0.933 \\
(0.936)\end{array}$ & & & & & & & \\
\hline SOW (4) & $\begin{array}{c}0.919 \\
(0.912)\end{array}$ & $\begin{array}{c}0.938^{\mathrm{c}} \\
(0.824)^{\mathrm{c}}\end{array}$ & $\begin{array}{c}0.364 \\
(0.347)\end{array}$ & $\begin{array}{c}0.224 \\
(0.198)\end{array}$ & $\begin{array}{c}0.344 \\
(0.348)\end{array}$ & $\begin{array}{c}0.959 \\
(0.955)\end{array}$ & & & & & & \\
\hline REPINT (5) & $\begin{array}{c}0.808 \\
(0.726)\end{array}$ & $\begin{array}{c}0.955 \\
(0.929)\end{array}$ & $\begin{array}{c}0.699 \\
(0.674)\end{array}$ & $\begin{array}{c}0.485 \\
(0.479)\end{array}$ & $\begin{array}{c}0.628 \\
(0.691)\end{array}$ & $\begin{array}{c}0.531 \\
(0.603)\end{array}$ & $\begin{array}{c}0.899 \\
(0.852)\end{array}$ & & & & & \\
\hline RECINT (6) & $\begin{array}{c}0.946 \\
(0.968)\end{array}$ & $\begin{array}{c}0.892^{\mathrm{c}} \\
(0.936)^{\mathrm{c}}\end{array}$ & $\begin{array}{c}0.761 \\
(0.700)\end{array}$ & $\begin{array}{c}0.420 \\
(0.487)\end{array}$ & $\begin{array}{c}0.856 \\
(0.728)\end{array}$ & $\begin{array}{c}0.368 \\
(0.350)\end{array}$ & $\begin{array}{c}0.666 \\
(0.743)\end{array}$ & $\begin{array}{c}0.973 \\
(0.984)\end{array}$ & & & & \\
\hline GENDER (7) & - & - & $\begin{array}{l}-0.135 \\
(0.240)\end{array}$ & $\begin{array}{c}0.044 \\
(0.139)\end{array}$ & $\begin{array}{c}-0.074 \\
(0.280)\end{array}$ & $\begin{array}{c}0.053 \\
(0.009)\end{array}$ & $\begin{array}{l}-0.031 \\
(0.187)\end{array}$ & $\begin{array}{l}-0.063 \\
(0.280)\end{array}$ & $\mathbf{n} / \mathbf{a}$ & & & \\
\hline AGE (8) & - & - & $\begin{array}{c}-0.009 \\
(-0.066)\end{array}$ & $\begin{array}{c}-0.077 \\
(-0.044)\end{array}$ & $\begin{array}{c}-0.051 \\
(-0.031)\end{array}$ & $\begin{array}{l}-0.094 \\
(0.043)\end{array}$ & $\begin{array}{c}-0.055 \\
(-0.058)\end{array}$ & $\begin{array}{c}-0.079 \\
(-0.082)\end{array}$ & $\begin{array}{c}0.044 \\
(-0.125)\end{array}$ & $\mathbf{n} / \mathbf{a}$ & & \\
\hline INCOME (9) & - & - & $\begin{array}{c}-0.068 \\
(-0.005)\end{array}$ & $\begin{array}{c}0.040 \\
(0.103)\end{array}$ & $\begin{array}{l}-0.066 \\
(0.023)\end{array}$ & $\begin{array}{c}0.113 \\
(0.056)\end{array}$ & $\begin{array}{l}-0.013 \\
(0.136)\end{array}$ & $\begin{array}{l}-0.051 \\
(0.114)\end{array}$ & $\begin{array}{c}0.133 \\
(-0.032)\end{array}$ & $\begin{array}{l}0.011 \\
0.240\end{array}$ & $\mathbf{n} / \mathbf{a}$ & \\
\hline RELLTH (10) & - & - & $\begin{array}{c}0.078 \\
(-0.055)\end{array}$ & $\begin{array}{c}0.101 \\
(-0.089)\end{array}$ & $\begin{array}{c}0.089 \\
(0.011)\end{array}$ & $\begin{array}{c}0.327 \\
(-0.095)\end{array}$ & $\begin{array}{c}0.180 \\
(-0.097)\end{array}$ & $\begin{array}{c}0.132 \\
(-0.032)\end{array}$ & $\begin{array}{c}0.104 \\
(-0.067)\end{array}$ & $\begin{array}{c}0.071 \\
(0.202)\end{array}$ & $\begin{array}{c}0.182 \\
(0.136)\end{array}$ & $\mathbf{n} / \mathbf{a}$ \\
\hline Mean & & & $\begin{array}{c}6.64 \\
(7.64)\end{array}$ & $\begin{array}{c}5.40 \\
(5.74)\end{array}$ & $\begin{array}{c}7.23 \\
(7.92)\end{array}$ & $\begin{array}{c}4.29 \\
(6.19)\end{array}$ & $\begin{array}{c}6.24 \\
(7.05)\end{array}$ & $\begin{array}{c}7.39 \\
(8.13)\end{array}$ & - & - & - & - \\
\hline $\mathrm{SD}^{\mathrm{b}}$ & & & $\begin{array}{c}1.72 \\
(1.63)\end{array}$ & $\begin{array}{c}2.43 \\
(2.99)\end{array}$ & $\begin{array}{c}1.66 \\
(1.62)\end{array}$ & $\begin{array}{c}2.85 \\
(2.91)\end{array}$ & $\begin{array}{c}2.25 \\
(2.48)\end{array}$ & $\begin{array}{c}1.99 \\
(2.18)\end{array}$ & - & - & - & - \\
\hline
\end{tabular}

Notes:

Results for grocery shown in parentheses

${ }^{\mathrm{a}} \mathrm{CR}=$ Composite reliability

${ }^{\mathrm{b}} \mathrm{SD}=$ Standard deviation;

${ }^{\mathrm{c}}$ Correlation coefficient. Construct measured with two items; CR cannot be computed.

PEVA $=$ Perceived value

SAT $=$ Satisfaction

REPINT $=$ Repurchase intention

RECINT $=$ Recommend intention

SOW $=$ Share-of-wallet

$\mathrm{WSI}=$ Willingness to share information

RELLTH $=$ Relationship length 
Table 3: PLS results

\begin{tabular}{|c|c|c|c|c|c|}
\hline Direct effects, effect sizes & $\beta$ & $f^{2}$ & $\beta$ & $f^{2}$ & Hypothesis test \\
\hline & \multicolumn{2}{|c|}{$D I Y$} & \multicolumn{2}{|c|}{ Grocery } & \\
\hline H1: Perceived value $\rightarrow$ Repurchase intention & $0.393 * * *$ & 0.165 & $0.195 * * *$ & 0.030 & Supported \\
\hline H2: Perceived value $\rightarrow$ Recommend intention & $0.253 * * *$ & 0.114 & $0.236^{* * *}$ & 0.036 & Supported \\
\hline H3: Perceived value $\rightarrow$ Share-of-wallet & $0.219 * * *$ & 0.023 & $0.173 * * *$ & 0.009 & Supported \\
\hline H4: Perceived value $\rightarrow$ WSI $^{\mathrm{a}}$ & $0.294 * * *$ & 0.044 & $0.194 * * *$ & 0.013 & Supported \\
\hline H5: Satisfaction $\rightarrow$ Repurchase intention & $0.160 * * *$ & 0.029 & $0.304 * * *$ & 0.069 & Supported \\
\hline H6: Satisfaction $\rightarrow$ Recommend intention & $0.627 * * *$ & 0.755 & $0.390 * * *$ & 0.094 & Supported \\
\hline H7: Satisfaction $\rightarrow$ Share-of-wallet & $0.151 * * *$ & 0.011 & $0.181 * * *$ & 0.010 & Supported \\
\hline H8: Satisfaction $\rightarrow$ WSI & $0.155^{* * *}$ & 0.014 & $0.280 * * *$ & 0.026 & Supported \\
\hline H9: WSI $\rightarrow$ Share-of-wallet & $0.078 * *$ & 0.009 & $0.042 \mathrm{~ns}$ & 0.002 & Partially supported \\
\hline H10: WSI $\rightarrow$ Repurchase intention & $0.198 * * *$ & 0.084 & $0.168 * * *$ & 0.066 & Supported \\
\hline H11: WSI $\rightarrow$ Recommend intention & $0.068 * * *$ & 0.016 & $0.167 * * *$ & 0.054 & Supported \\
\hline H12: Share-of-wallet $\rightarrow$ Repurchase intention & $0.282 * * *$ & 0.159 & $0.390 * * *$ & 0.392 & Supported \\
\hline H13: Share-of-wallet $\rightarrow$ Recommend intention & $0.028 \mathrm{~ns}$ & 0.003 & $0.096^{* *}$ & 0.020 & Partially supported \\
\hline Gender $\rightarrow$ Repurchase intention & $0.010 \mathrm{~ns}$ & 0.000 & $0.022 \mathrm{~ns}$ & 0.001 & \\
\hline Gender $\rightarrow$ Recommend intention & $0.011 \mathrm{~ns}$ & 0.001 & $0.085^{* * *}$ & 0.016 & \\
\hline Age $\rightarrow$ Repurchase intention & $-0.003 \mathrm{~ns}$ & 0.000 & $-0.048 \mathrm{~ns}$ & 0.006 & \\
\hline Age $\rightarrow$ Recommend intention & $-0.040 \mathrm{~ns}$ & 0.007 & $-0.066 \mathrm{~ns}$ & 0.010 & \\
\hline Income $\rightarrow$ Repurchase intention & $-0.021 \mathrm{~ns}$ & 0.001 & $0.054 \mathrm{~ns}$ & 0.008 & \\
\hline Income $\rightarrow$ Recommend intention & $-0.007 \mathrm{~ns}$ & 0.000 & $0.101^{* * *}$ & 0.024 & \\
\hline Relationship length $\rightarrow$ Repurchase intention & $0.026 \mathrm{~ns}$ & 0.002 & $-0.035 \mathrm{~ns}$ & 0.003 & \\
\hline Relationship length $\rightarrow$ Recommend intention & $0.044 * *$ & 0.007 & $0.006 \mathrm{~ns}$ & 0.000 & \\
\hline$R^{2}$ & $R^{2}$ & & $R^{2}$ & & \\
\hline WSI & 0.17 & & 0.20 & & \\
\hline Share-of-wallet & 0.14 & & 0.13 & & \\
\hline Repurchase intention & 0.62 & & 0.67 & & \\
\hline Recommend intention & 0.77 & & 0.60 & & \\
\hline
\end{tabular}

Notes:

*** $p<0.01 ; * * p<0.05$; ns $=$ not significant

${ }^{a}$ WSI - Willingness to share information 
Table 4: Indirect effects and total effects

\begin{tabular}{|c|c|c|}
\hline & Indirect effects & Total effects \\
\hline \multirow{2}{*}{ Perceived value $\rightarrow$ Share of wallet } & $0.023 \mathrm{~ns}$ & $0.242 * * *$ \\
\hline & $(0.008 \mathrm{~ns})$ & $(0.181 * * *)$ \\
\hline \multirow[t]{2}{*}{ Perceived value $\rightarrow$ Repurchase intention } & $0.127 * * *$ & $0.520 * * *$ \\
\hline & $(0.103 * * *)$ & $(0.299 * * *)$ \\
\hline \multirow[t]{2}{*}{ Perceived value $\rightarrow$ Recommend intention } & $0.027 * * *$ & $0.280 * * *$ \\
\hline & $\left(0.050^{* * *}\right)$ & $(0.285 * * *)$ \\
\hline \multirow[t]{2}{*}{ Satisfaction $\rightarrow$ Share of wallet } & $0.012 \mathrm{~ns}$ & $0.163 * * *$ \\
\hline & $(0.013 \mathrm{~ns})$ & $(0.193 * * *)$ \\
\hline \multirow[t]{2}{*}{ Satisfaction $\rightarrow$ Repurchase intention } & $0.077 * * *$ & $0.237 * * *$ \\
\hline & $(0.122 * * *)$ & $0.427 * * *)$ \\
\hline \multirow[t]{2}{*}{ Satisfaction $\rightarrow$ Recommend intention } & $0.015^{* * *}$ & $0.642 * * *$ \\
\hline & $\left(0.065^{* * *}\right)$ & $(0.455 * * *)$ \\
\hline \multirow[t]{2}{*}{ Willingness to share information $\rightarrow$ Repurchase intention } & $0.022 * *$ & $0.220 * * *$ \\
\hline & $(0.016 \mathrm{~ns})$ & $(0.184 * * *)$ \\
\hline \multirow[t]{2}{*}{ Willingness to share information $\rightarrow$ Recommend intention } & $0.002 \mathrm{~ns}$ & $0.070^{* * *}$ \\
\hline & $(0.004 \mathrm{~ns})$ & $\left(0.171^{* * *}\right)$ \\
\hline
\end{tabular}

Notes:

Results for grocery shown in parentheses

$* * * p<0.01 ; * * p<0.05$; ns $=$ not significant 


\section{Appendix}

Table 5. Measurement scales

\begin{tabular}{|c|c|c|}
\hline \multirow[t]{2}{*}{ Constructs and items } & \multicolumn{2}{|c|}{ Factor loadings $^{\mathrm{a}}$} \\
\hline & $D I Y$ & Grocery \\
\hline \multicolumn{3}{|l|}{ Perceived value ${ }^{\mathrm{b}}$} \\
\hline What is your overall satisfaction with [company X's] prices? & 0.912 & 0.900 \\
\hline [Company X's] products and services are reasonably priced. & 0.944 & 0.939 \\
\hline [Company X] provides good products and services for the price. & 0.950 & 0.951 \\
\hline [Company X] would be economical. & 0.908 & 0.914 \\
\hline [Company X] offers value for money. & 0.953 & 0.954 \\
\hline \multicolumn{3}{|l|}{ Satisfaction ${ }^{\mathrm{c}}$} \\
\hline What is your overall satisfaction with [company $\mathrm{X}]$ ? & 0.927 & 0.928 \\
\hline To what extent has [company $\mathrm{X}]$ met our expectations? & 0.942 & 0.948 \\
\hline $\begin{array}{l}\text { How well did [company X] compare with the ideal type of [grocery / DIY] } \\
\text { retailer? }\end{array}$ & 0.931 & 0.931 \\
\hline \multicolumn{3}{|l|}{ Willingness to share information ${ }^{\mathrm{d}}$} \\
\hline I am willing to provide this company with information about me. & 0.946 & 0.965 \\
\hline $\begin{array}{l}\text { I am willing to provide this company with information about my } \\
\text { product needs and preferences. }\end{array}$ & 0.949 & 0.966 \\
\hline \multicolumn{3}{|l|}{ Share-of-wallet ${ }^{\mathrm{e}}$} \\
\hline $\begin{array}{l}\text { What percentage of your total expenditures for [groceries / DIY] do you spend } \\
\text { in this store? }\end{array}$ & 0.958 & 0.961 \\
\hline $\begin{array}{l}\text { Of the } 10 \text { times you select a store to buy [groceries / DIY] at, how many times } \\
\text { do you select this store? }\end{array}$ & 0.960 & 0.948 \\
\hline \multicolumn{3}{|l|}{ Repurchase intention $^{\mathrm{f}}$} \\
\hline I consider [company X] as my first choice for [groceries / DIY] & 0.890 & 0.832 \\
\hline I continue purchasing [groceries / DIY] at [company X] & 0.844 & 0.737 \\
\hline I increase my frequency of purchasing at [company X] & 0.927 & 0.897 \\
\hline I increase how much I purchase at [company X]. & 0.946 & 0.912 \\
\hline I purchase more expensive [groceries / DIY] at [company X]. & 0.884 & 0.869 \\
\hline \multicolumn{3}{|l|}{ Recommend intention ${ }^{\mathrm{g}}$} \\
\hline $\begin{array}{l}\text { How likely is it that you would recommend [company } \mathrm{X} \text { ] to a colleague or } \\
\text { friend? }\end{array}$ & 0.974 & 0.984 \\
\hline $\begin{array}{l}\text { How likely is it that you would say positive things about [company } \mathrm{X}] \text { to other } \\
\text { people? }\end{array}$ & 0.972 & 0.984 \\
\hline
\end{tabular}


Notes:

a All signifant at $p<0.01$

Scale sources:

${ }^{\mathrm{b}}$ Perceived value - Sweeney and Soutar (2001); ${ }^{\mathrm{c}}$ Satisfaction - Fornell et al. (1996); ${ }^{\mathrm{d}}$ Willingness to share

information -Schoenbacler and Gordon (2002); ${ }^{\mathrm{e}}$ Share-of-wallet - Wulf et al. (2001); ${ }^{\mathrm{f}}$ Repurchase intention -

Lam et al. (2004) and Zeithaml et al. (1996); ${ }^{\mathrm{g}}$ Recommend intention - Reichheld (2003) and Zeithaml et al. (1996). 


\section{LIST OF FIGURES}

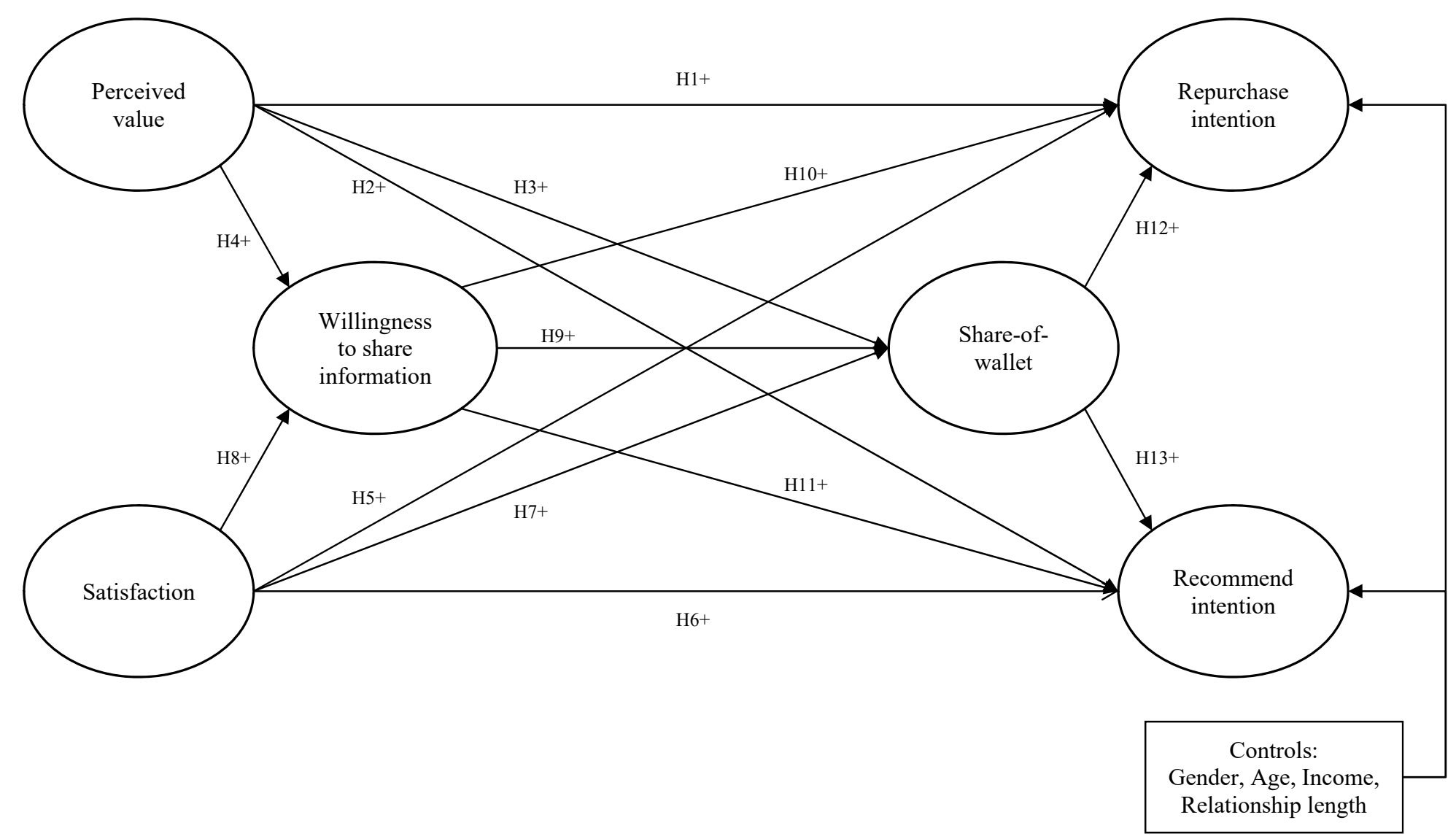

Figure 1. Conceptual model and hypotheses 